\title{
Non-autoimmune subclinical hypothyroidism due to a mutation in TSH receptor: report on two brothers
}

\author{
Manuela Cerbone1, Patrizia Agretti², Giuseppina De Marco², Nicola Improda', Claudio Pignata1, \\ Francesca Santamaria ${ }^{1}$, Massimo Tonacchera ${ }^{2}$ and Mariacarolina Salerno ${ }^{1^{*}}$
}

\begin{abstract}
Subclinical hypothyroidism $(\mathrm{SH})$ is a condition characterized by a mild persistent thyroid failure. The main cause is represented by autoimmune thyroiditis, but mutations in genes encoding proteins involved in TSH pathway are thought to be responsible for SH, particularly in cases arising in familial settings. Patients with the syndrome of TSH unresponsiveness may have compensated or overt hypothyroidism with a wide spectrum of clinical and morphological alterations depending on the degree of impairment of TSH-receptor (TSH-R) function. We describe the case of two brothers with non autoimmune SH carrying the same heterozygous mutation in the extracellular domain of TSH-R and presenting with different clinical, biochemical and morphological features. The first one had only a slight persistent elevation of TSH, a normal thyroid ultrasound and did never require I- thyroxine (L-T4) replacement treatment. The second one had a neonatal persistent moderate TSH levels increase associated with a thyroid gland hypoplasia and was treated with L-T4 since the first months of life.

These two cases support the recent association of TSH-R mutations inheritance as an autosomal dominant pattern with variable expressivity and suggest that the decision to start replacement therapy in patients with persistent $\mathrm{SH}$ due to TSH resistance should be individualized.
\end{abstract}

Keywords: Subclinical hypothyroidism, Congenital hypothyroidism, TSH receptor mutation, Growth

\section{Background}

Subclinical hypothyroidism $(\mathrm{SH})$ is a biochemical condition characterized by serum levels of TSH above the statistically defined upper limit of reference range, with normal concentrations of thyroid hormones and without severe clinical features of hypothyroidism [1]. The prevalence has been reported to be between 4 and $20 \%$ of the adult population [2] and about $1.7 \%$ in US children [3]. However, in childhood it seems to be a benign remitting condition with a low risk of progression to overt hypothyroidism [1,4-8]. During neonatal period, a slight increase in TSH levels with normal thyroid hormone may be transient and sometimes be the cause of a false positive at neonatal screening for congenital hypothyroidism $(\mathrm{CH})$ [9]. However, in other cases it may also be the expression of a mild persistent thyroid failure due to genetic abnormalities of thyroid

\footnotetext{
* Correspondence: salerno@unina.it

'Department of Pediatrics, University of Naples "Federico II", Naples, Italy

Full list of author information is available at the end of the article
}

structure or function. The most frequent cause of persistent $\mathrm{SH}$ in childhood is represented by autoimmune thyroiditis. However, iodine deficiency, obesity, non-thyroidal chronic diseases or inherited syndromes may also be responsible for mild increase of TSH levels. When no overt causes of slight TSH increase are detectable the condition is defined as idiopathic SH [10]. Mutations in genes encoding proteins involved in TSH pathway are thought to be responsible for some cases of idiopathic $\mathrm{SH}$, particularly in cases arising in familial settings $[11,12]$. TSH exerts its activity by binding to the extracellular domain of TSH receptor (TSH-R). TSH-R is a member of the G protein-coupled receptor family that also includes calcitonin and PTH receptors [13]. It mediates the effects of TSH in thyroid development, growth, and thyroid hormone synthesis. Here we describe the case of two brothers with non autoimmune SH carrying the same TSH-R mutation and presenting with different clinical, biochemical and morphological features.

\section{()




\section{Case presentation}

Patient 1 was a young boy admitted to our Pediatric Endocrinology Unit at the age of 8-years for the finding of isolated hyperthyreotropinemia. He was the first child of healthy unrelated parents. Two blood samples performed three months apart showed a slight increase in TSH levels (TSH: $8 \mu \mathrm{U} / \mathrm{ml}$, normal range: $0.5-4.5$ ) with normal FT4 concentration (FT4 $1.2 \mathrm{ng} / \mathrm{dl}$, normal range: $0.7-1.6)$. The neonatal history was normal, he was not affected by any chronic disease, and was not taking any drugs potentially interfering with thyroid function. The reason for thyroid function screening was the familiarity for thyroid diseases. In fact, the younger brother was affected by $\mathrm{CH}$ and was treated with L-T4 since he was 4-months-old. The physical examination was normal, no signs or symptoms of hypothyroidism goiter included were detectable. Auxological parameters were normal, both weight and height being between 50th-75th percentile; height was appropriate to the genetic familial target. Autoimmune thyroiditis, morphological anomalies of thyroid gland, iodine deficiency and pseudohypoparathyroidism, were excluded by clinical, biochemical and ultrasound evaluation. He was not treated with L-T4 due to the slight elevation of TSH (ranging always between 4.5 and $10 \mu \mathrm{U} / \mathrm{ml}$ ) and was closely monitored with clinical and laboratory examinations. At the age of 10 years, because of the persistence of $\mathrm{SH}$ and the familiarity for thyroid diseases, molecular analysis for TSH-R was performed. Direct sequencing of the extracellular and transmembrane-coding regions of the TSH-R showed an heterozygous missense mutation (CGG to $\mathrm{CAG}$ ) in the exon 4 corresponding to an arginine to glutamine change at codon 109 (R109Q) in the extracellular domain of the receptor. The patient is now 18 years old. During the follow-up, despite a persistent slight elevation of $\mathrm{TSH}$, he never required L-T4 replacement therapy. He always presented a normal growth and bone maturation. Puberty began and progressed regularly and the evaluation of intellectual outcome at the age of 16 years was normal with an intellectual quotient (IQ) of 108.

Patient 2, the younger brother of patient 1, was referred to our Unit at the age of 8 years for $\mathrm{CH}$. The diagnosis of $\mathrm{CH}$ was performed on the basis of persistent moderate hyperthyreotropinemia ( $\mathrm{TSH} 12-15 \mu \mathrm{U} / \mathrm{ml}$ ) with low-normal values of FT4 (FT4 $0.8 \mathrm{ng} / \mathrm{dl}$; normal values $0.7-1.7$ ), and a mild gland hypoplasia at thyroid ultrasound, incidentally discovered during a laboratory evaluation for growth retardation. The treatment with L-T4 was started at the age of 4 months with an initial dose of $6 \mu \mathrm{g} / \mathrm{kg} /$ day. Due to the finding of a TSH-R mutation in the older brother, we decided to re-evaluate the diagnosis of $\mathrm{CH}$. The TSH-R molecular analysis showed the same heterozygous missense mutation of the brother, thus we decided to stop L-T4 therapy.
However, TSH levels raised in a month over $10 \mu \mathrm{U} / \mathrm{ml}$ and persisted elevated in the following 3 measurements, ranging between 13 and $18 \mu \mathrm{U} / \mathrm{ml}$. Moreover, he reported clinical symptoms of hypothyroidism such as fatigue, mood changes and impaired concentration in addition to significant weight gain. Therefore, L-T4 therapy was promptly re-started. During the follow-up he presented a normal growth and bone maturation. The puberty began and progressed regularly but the evaluation of IQ at the age of 16 years was slightly low (IQ 80).

\section{Discussion}

Subclinical hypothyroidism is a relatively common condition characterized by a mild thyroid failure. It can occur at any age from neonatal period to adulthood in both transient or persistent form. Newborns with SH may have a transient impairment of thyroid function due to environmental or mother-derived causes, but they can also have genetic abnormalities of thyroid structure and function. During childhood the main cause of $\mathrm{SH}$ is generally represented by autoimmune $\mathrm{SH}$, other known causes being mild developmental thyroid abnormalities, iodine deficiency, obesity, non-thyroidal chronic diseases or inherited syndromes and mutations in the TSH-R gene. Loss of function mutations in genes encoding proteins involved in the TSH pathway, TSH- $\mathrm{R}$ anomalies or alterations in the proteins involved in the signaling pathway downstream the receptor, have been widely demonstrated to be responsible of $\mathrm{SH}$ [11,14-18]. In a recent study, Rapa et al. evaluated the clinical characteristics and TSH-R gene variation in a series of children with slight to moderate elevation of TSH with normal thyroid hormone due to non autoimmune $\mathrm{SH}$. Non-synonymous mutations of TSH-R gene or polymorphisms were found in $21.5 \%$ of cases [14]. The prevalence of a positive family history of thyroid diseases was two-fold higher in patients with mutations than in those with no mutations. An even higher prevalence of mutation in the TSH-R gene (29\%) was detected by Nicoletti et al. [11]. Eleven mutations of TSH-R gene were identified in a cohort of 38 children and adolescents with non-autoimmune $\mathrm{SH}$. In our first patient the main causes of persistent $\mathrm{SH}$ were ruled out at first examination. The diagnosis of partial resistance to TSH was suggested by the familiar history of thyroid diseases. Although both sibs were carrying the same mutation, they had completely different clinical phenotype. The first boy had a slight persistent increase of TSH (less than $10 \mu \mathrm{U} / \mathrm{ml}$ ), normal thyroid ultrasound and did not show any signs or symptoms of mild hypothyroidism requiring L-T4 treatment. Conversely, the younger brother presented a moderate increase of TSH with serum levels persistently above $10 \mu \mathrm{U} / \mathrm{ml}$ with low normal serum FT4 concentrations, morphological thyroid anomalies with a mild thyroid hypoplasia. He needed to be treated in early infancy and 
relapsed when treatment was withdrawn. Indeed, even with a mild increase in TSH levels, he presented slight symptoms of hypothyroidism that prompted us to restore L-T4 treatment. Despite treatment, his IQ was slightly low thus raising the question on whether the delay in starting replacement treatment or a low initial dose of L-T4 may have influenced the suboptimal IQ outcome [19]. Pituitary TSH is critical for thyroid development and function and exerts its activity by binding to the extracellular domain of TSH-R, a G protein-coupled seven-transmembrane domain receptor located in the basolateral membrane of thyroid follicular cells. The principal biological effects of TSH on the thyrocite occur by receptor-mediated activation of Gs $\alpha$ and subsequent generation of intracellular cAMP [20,21]. The human TSH-R gene is located on chromosome 14q31 and encodes a protein of 764 amino acids. The gene is comprised of 10 exons, with the first nine encoding the extracellular domain and the large exon 10 encoding the transmembrane domain and the cytoplasmic tail [14]. Patients with the syndrome of TSH unresponsiveness may have compensated [17,22-24] or overt hypothyroidism [25-30] depending on the presence of a partial or complete TSH resistance. These conditions include a wide spectrum of biochemical, as well as clinical and morphological alterations depending on the degree of impairment of TSH-R function. The metabolic consequences can range from mild $\mathrm{SH}$ to severe $\mathrm{CH}$. TSH is a prerequisite not only for normal thyroid hormone synthesis but also for proliferation. Accordingly, the inherited $\mathrm{CH}$ in the hyt/ hyt mouse was shown to be caused by homozygosity for a loss of function mutation of the TSH-R (P556L) leading to thyroid hypoplasia and severe $\mathrm{CH}$ [29]. The mutation R109Q in the extracellular domain of TSH-xR, found in our two brothers, was first described by Clifton-Bligh et al. in a child compound heterozygote for another missense mutation in the fourth transmembrane segment of receptor. This child presented with markedly increased serum TSH concentrations and low normal thyroid hormone levels identified after a positive result on neonatal screening for $\mathrm{CH}$, normal thyroid morphology and treated with L-T4 since 8 weeks of age [17]. Similarly to our second patient, after the L-T4 withdrawal at the age of 2 years, he showed a significant increase of TSH levels that required a resumption of therapy. Moreover, the R109Q mutation has also been documented in Italian children with non-autoimmune $\mathrm{SH}[11,14]$. In particular, the two siblings reported by Nicoletti et al. [11], carrying the same heterozygous R109Q loss of function mutation found in our two patients, had a mild phenotype characterized by a slightly increase in serum TSH, normal thyroid gland at ultrasound and no clinical features of thyroid dysfunction. Similarly to our first patient they do not need treatment, thus highlighting the wide phenotypic variability in children with $\mathrm{SH}$ due to the same TSH-R mutation. In the earlier studies in which only probands with large TSH elevations were screened for mutations, the disease was linked to homozygous or compound heterozygous mutations and was described to follow a recessive pattern of inheritance [17,18,20-29]. More recently inheritance of TSH-R resistance has been associated with an autosomal dominant pattern without evidence for incomplete penetrance, but with variable expressivity. Several families have been described with dominant transmission of partial TSH resistance due to heterozygous inactivating mutations in TSH-R [30,31]. The recent finding that TSH- $\mathrm{R}$, like other $\mathrm{G}$ proteincoupled receptors, can oligomerize in living cells led to the hypothesis that the formation of complexes between wild-type and mutant receptors may be responsible for partial TSH resistance in patients with heterozygous TSH-R mutations [31]. The clinical heterogeneity in our 2 patients carrying the same mutation, is not surprising as other monogenic diseases have been already shown to have a different phenotype despite the same causing mutation [32-36]. For most of these conditions, molecular basis of this heterogeneity are not well delineated. Disease modifying genes, variation in environmental exposures, as well as system dynamics may come into play in modulating clinical expression of the disease. If the treatment should be indicated or not in patients with only slight elevation of TSH due to TSH-R resistance is controversial. In fact, the elevation of circulating TSH would represent the compensatory mechanism allowing gland development and the maintenance of a normal thyroid hormone secretion in the presence of partial refractoriness to TSH action. Currently, there is no evidence that children with only slight increase in TSH levels (less than $10 \mu \mathrm{U} / \mathrm{ml}$ ) and normal FT4 concentrations suffer any clinical or neurological abnormality that would be eventually restored to normal by L-T4 treatment $[6,8]$. Therefore the decision to treat with L-T4 $\mathrm{SH}$ still represents a clinical dilemma.

\section{Conclusions}

Patients with persistent non autoimmune hyperthyreotropinemia should be investigated for TSH-R gene, in particular in cases arising in familial settings, even though the majority of patients with an heterozygous TSH-R loss of function mutation have only mild $\mathrm{SH}$ generally not requiring any treatment. However, it should be mentioned that some cases may have a more severe clinical presentation with the need of lifelong treatment. Currently is not possible to predict the clinical presentation and the evolution of these patients based on genetic features.

\section{Consent}

Written informed consent was obtained from the parents of the patient for publication of this Case report and any accompanying images. A copy of the written 
consent is available for review by the Editor-in-Chief of this journal.

\section{Abbreviations}

SH: Subclinical hypothyroidism; TSH-R: TSH-receptor; L-T4: I- thyroxine; $\mathrm{CH}$ : Congenital hypothyroidism; IQ: Intellectual quotient.

\section{Competing interests}

The authors declare that they have no competing interests.

\section{Authors' contributions}

All authors have equally participated in drafting of the manuscript and/or critical revision of the manuscript for important intellectual content. All authors read and approved the final manuscript.

\section{Author details}

'Department of Pediatrics, University of Naples "Federico II", Naples, Italy. ${ }^{2}$ Department of Endocrinology and Metabolism, University of Pisa, Pisa, Italy.

Received: 15 September 2012 Accepted: 15 January 2013

Published: 19 January 2013

\section{References}

1. Surks Ml, Ortiz E, Daniels GH, Sawin CT, Col NF, Cobin RH, Franklyn JA, Hershman JM, Burman KD, Denke MA, Gorman C, Cooper RS, Weissman NJ: Subclinical thyroid disease: scientific review and guidelines for diagnosis and management. JAMA 2004, 291:228-238.

2. Biondi B: Natural history, diagnosis and management of subclinical thyroid disfunction. Best Pract Res Clin Endocrinol Metab 2012, 26:431-446.

3. Wu T, Flowers JW, Tudiver F, Wilson JL, Punyasavatsut N: Subclinical thyroid disorders and cognitive performance among adolescents in the United States. BMC Pediatr 2006, 6:12.

4. Paolo Valeri M, Maman-Alvardo D, Mayor G, Ridgway EC: Frequency of subclinical hypothyroidism among healthy children and those with neurological conditions in the state of Merida, Venezuela. Invest Clin 2000, 44:209-218.

5. Radetti G, Maselli M, Buzi F, Corrias A, Mussa A, Cambiaso P, Salerno M, Cappa M, Baiocchi M, Gastaldi R, Minerba L, Loche S: The natural history of the normal/mild elevated TSH serum levels in children and adolescents with Hashimoto's thyroiditis and isolated hyperthyrotropinaemia: a 3-year follow-up. Clin Endocrinol 2012, 76:394-398.

6. Wasniewska M, Salerno M, Cassio A, Corrias A, Aversa T, Zirilli G, Capalbo D, Bal M, Mussa A, De Luca F: Prospective evaluation of the natural course of idiopathic subclinical hypothyroidism in childhood and adolescence. Eur J Endocrinol 2009, 160:417-421.

7. Wasniewska M, Corrias A, Aversa T, Valenzise M, Mussa A, De Martino L, Lombardo F, De Luca F, Salerno M: Comparative evaluation of therapy with L-Thyroxine versus no treatment in children with idiopathic and mild subclinical hypothyroidism. Horm Res Paediatr 2012, 77:376-381.

8. Cerbone M, Bravaccio C, Capalbo D, Polizzi M, Wasniewska M, Cioffi D, Improda N, Valenzise M, Bruzzese D, De Luca F, Salerno M: Linear growth and intellectual outcome in children with long-term idiopathic subclinical hypothyroidism. Eur J Endocrinol 2011, 164:591-597.

9. Leonardi D, Polizzotti N, Carta A, Gelsomino R, Sava L, Vigneri R, Calaciuria F: Longitudinal study of thyroid function in children with hyperthyrotropinemia at neonatal screening for congenital hypothyroidism. J Clin Endocrinol Metab 2008, 93:2679-2685.

10. Arrigo T, Wasniwska M, Crisafulli G, Lombardo F, Messina MF, Rulli I, Salzano G, Valenzise M, Zirilli G, De Luca F: Subclinical hypothyroidism: the state of art. J Endocr Invest 2008, 31:79-84.

11. Nicoletti A, Bal M, De Marco G, Baldazzi L, Agretti P, Menabò S, Ballarini E, Cicognani A, Tonacchera M, Cassio A: Thyrotropin-stimulating hormone receptor gene analysis in pediatric patients with non-autoimmune subclinical hypothyroidism. J Clin Endocrinol Metab 2009, 94:4187-4194.

12. Alberti L, Proverbio MC, Costagliola S, Romoli R, Boldrighini B, Vigone MC, Weber G, Chiumello G, Beck-Peccoz P, Persani L: Germline mutations of TSH receptor gene as cause of non-autoimmune subclinical hypothyroidism. J Clin Endocrinol Metab 2002, 87:2549-2555.

13. De Sanctis L, Romagnolo D, Olivero M, Buzi F, Maghnie M, Scirè G, Crino A Baroncelli Gl, Salerno M, Di Maio S, Cappa M, Grosso S, Rigon F, Lala R, De Sanctis C, Dianzani I: Molecular analysis of the GNAS1 gene for the correct diagnosis of Albright hereditary osteodystrophy and pseudohypoparathyroidism. Pediatr Res 2003, 53:749-755.

14. Rapa A, Monzani A, Moia S, Vivenza D, Bellone S, Petri A, Teofoli F, Cassio A, Cesaretti G, Corrias A, de Sanctis V, Di Maio S, Volta C, Wasniewska M, Tatò L, Bona G: Subclinical hypothyroidism in children and adolescents: a wide range of clinical, biochemical, and genetic factors involved. J Clin Endocrinol Metab 2009, 94:2414-2420.

15. Duprez L, Parma J, Van Sande J, Rodien P, Dumont JE, Vassart G, Abramowic M: TSH receptor mutations and thyroid disease. Trends Endocrinol Metab 1998, 9:133-140.

16. Tonacchera M, Di Cosmo C, De Marco G, Agretti P, Banco M, Perri A, Gianetti E, Montanelli L, Vitti P, Pinchera A: Identification of TSH receptor mutations in three families with resistance to TSH. Clin Endocrinol 2007, 67:712-718

17. Clifton-Bligh RJ, Gregory JW, Ludgate M, John R, Persani L, Asteria C, BeckPeccoz P, Chatterjee VK: Two novel mutations in the thyrotropin (TSH) receptor gene in a child with resistance to TSH. J Clin Endocrinol Metab 1997, 82:1094-1100

18. Camilot M, Teofoli F, Gandini A, Franceschi R, Rapa A, Corrias A, Bona G, Radetti G, Tato' L: Thyrotropin receptor gene mutations and TSH resistance: variable expressivity in the heterozygotes. Clin Endocrinol 2005, 63:146-151.

19. Salerno M, Militerni R, Bravaccio C, Micillo M, Capalbo D, Di MS, Tenore A: Effect of different starting doses of levothyroxine on growth and intellectual outcome at four years of age in congenital hypothyroidism. Thyroid 2002, 12:45-52.

20. Vassart G, Dumont JE: The thyrotropin receptor and the regulation of thyrocyte function and growth. Endocrine Rev 1992, 13:596-611.

21. Tonacchera M, Van Sande J, Parma J, Duprez L, Cetani F, Costagliola S, Dumont JE, Vassart G: TSH receptor and disease. Clin Endocrinol 1996, 44:621-633

22. de Roux N, Misrahi M, Brauner P, Houang M, Carel JC, Granier M, Le Bouc $Y$, Ghinea N, Boumedienne A, Toublanc JE, Milgrom E: Four families with loss of function mutations of the thyrotropin receptor. J Clin Endocrinol Metab 1996, 81:4229-4235.

23. Russo D, Betterle C, Arturi F, Chiefari E, Girelli ME, Filetti S: A novel mutation in the thyrotropin (TSH) receptor gene causing loss of TSH binding but constitutive receptor activation in a family with resistance to TSH. J Clin Endocrinol Metab 2000, 85:4238-4242.

24. Sunthornthepvarakul T, Gottschalk ME, Hayashi Y, Refetoff S: Resistance to thyrotropin caused by mutations in the thyrotropin-receptor gene. N Engl J Med 1995, 332:155-160.

25. Bieberman H, Schoneberg T, Krude H, Schultz G, Guderman T, Gruters A: Mutations of the human thyrotropin receptor gene causing thyroid hypoplasia and persistent congenital hypothyroidism. J Clin Endocrino Metab 1997, 82:3471-3480

26. Abramowicz MJ, Duprez L, Parma J, Vassart G, Heinrichs C: Familia congenital hypothyroidism due to inactivating mutation of the thyrotropin causing profound hypoplasia of the thyroid gland. J Clin Invest 1997, 99:3018-3024.

27. Gagné N, Parma J, Deal C, Vassart G, Van Vliet G: Apparent congenital athyreosis contrasting with normal plasma thyroglobulin levels and associated with inactivating mutations in the thyrotropin receptor gene: are athyreosis and ectopic thyroid dinstinct entities? J Clin Endocrinol Metab 1998, 83:1771-1775.

28. Tiosano D, Pannain S, Vassart G, Parma J, Gershoni. Baruch R, Mandel H, Lotan R, Zaharan Y, Pery M, Weiss RE, Refetoff S, Hochberg Z: The hypothyroidism in an inbred kindred with congenital thyroid hormone and glucocorticoid deficiency is due to a mutation producing a truncated thyrotropin receptor. Thyroid 1999, 9:887-894.

29. Tonacchera $M$, Agretti P, Pinchera A, Rosellini V, Perri A, Collecchi P, Vitti P, Chiovato L: Congenital hypothyroidism with impaired thyroid response to thyrotropin (TSH) and absent circulating thyroglobulin: evidence for a new inactivating mutation of the TSH receptor gene. J Clin Endocrinol Metab 2000, 85:1001-1008.

30. Grasberger H, Mimouni-Bloch A, Vantyghem MC, van Vliet G, Abramowicz M, Metzger DL, Abdullatif H, Rydlewski C, Macchia PE, Scherberg NH, van Sande J, Mimouni M, Weiss RE, Vassart G, Refetoff S: Autosomal dominant resistance to thyrotropin as a distinct entity in five multigenerational kindreds: clinical characterization and exclusion of candidate loci. J Clin Endocrinol Metab 2005, 90:4025-4034. 
31. Calebiro D, de Filippis T, Lucchi S, Covino C, Panigone S, Beck-Peccoz P, Dunlap D, Persani L: Intracellular entrapment of wild-type TSH receptor by oligomerization with mutants linked to dominant TSH resistance. Hum Mol Genet 2005, 14:2991-3002.

32. Capalbo D, Fusco A, Aloj G, Improda N, Vitiello L, Dianzani U, Betterle C, Salerno M, Pignata: High intrafamilial variability in autoimmune polyendocrinopathy-candidiasis-ectodermal dystrophy: a case study. J Endocrinol Invest 2012, 35:77-81.

33. Capalbo D, Mazza C, Giordano R, Improda N, Arvat E, Cervato S, Morlin L, Pignata C, Betterle C, Salerno M: Molecular background and genotypephenotype correlation in autoimmune-polyendocrinopathy-candidiasisectodermal-distrophy patients from Campania and in their relatives. J Endocrinol Invest 2012, 35:169-173.

34. Mazza C, Buzi F, Ortolani F, Vitali A, Notarangelo LD, Weber G, Bacchetta R, Soresina A, Lougaris V, Greggio NA, Taddio A, Pasic S, de Vroede M, Pac M, Kilic SS, Ozden S, Rusconi R, Martino S, Capalbo D, Salerno M, Pignata C, Radetti G, Maggiore G, Plebani A, Notarangelo LD, Badolato R: Clinical heterogeneity and diagnostic delay of autoimmune polyendocrinopathy-candidiasis-ectodermal dystrophy syndrome. Clin Immunol 2011, 139:6-11.

35. Capalbo D, Melis D, De Martino L, Palamaro L, Riccomagno S, Bona G, Cordeddu V, Pignata C, Salerno M: Noonan-like syndrome with loose anagen hair associated with growth hormone insensitivity and atypical neurological manifestations. Am J Med Genet A 2012, 158A:856-860.

36. Gallo V, Giardino G, Capalbo D, Palamaro L, Romano R, Santamaria F, Maio F, Salerno M, Vajro P, Pignata C: Alterations of the autoimmune regulator transcription factor and failure of central tolerance: APECED as a model. Expert Rev Clin Immunol 2013, 9:43-45.

doi:10.1186/1824-7288-39-5

Cite this article as: Cerbone et al:: Non-autoimmune subclinical hypothyroidism due to a mutation in TSH receptor: report on two brothers. Italian Journal of Pediatrics 2013 39:5.

\section{Submit your next manuscript to BioMed Central and take full advantage of:}

- Convenient online submission

- Thorough peer review

- No space constraints or color figure charges

- Immediate publication on acceptance

- Inclusion in PubMed, CAS, Scopus and Google Scholar

- Research which is freely available for redistribution 